\begin{tabular}{|c|c|c|}
\hline \multirow{2}{*}{ BENTHAM OPEN } & $\begin{array}{c}\text { The Open Cybernetics \& Systemics } \\
\text { Journal }\end{array}$ & $\begin{array}{l}\text { The Open } \\
\text { Chberencics \& Ssistemics } \\
\text { loumal }\end{array}$ \\
\hline & $\begin{array}{c}\text { Content list available at: www.benthamopen.com/TOCSJ/ } \\
\text { DOI: } 10.2174 / 1874110 \mathrm{X} 01610010296\end{array}$ & $\Rightarrow$ \\
\hline
\end{tabular}

RETRACTION

\title{
Retraction Notice: The Study of the Reflection of Cost Control on Financial Management
}

Youming Hes ${ }^{*}$

Ningbo Polytechnic, Ningbo, China

\section{RETRACTION}

The Publisher and Editor have retracted this article [1] in accordance with good ethical practices. After thorough investigations we believe that the peer review process was compromised. The article was published online on 08-10-2015.

\section{REFERENCE}

[1] Y. He, "The study of the reflection of cost control on financial management", Open Cybern. Syst. J., vol. 9, pp. 1846-1848, 2015.

(C) Youming He; Licensee Bentham Open.

This is an open access article licensed under the terms of the Creative Commons Attribution-Non-Commercial 4.0 International Public License (CC BY-NC 4.0) (https://creativecommons.org/licenses/by-nc/4.0/legalcode), which permits unrestricted, non-commercial use, distribution and reproduction in any medium, provided the work is properly cited.

* Address correspondence to this author at the Ningbo Polytechnic, Ningbo, China; E-mail: cyyg015@sina.com 